IRA-International Journal of Education \& Multidisciplinary Studies

ISSN 2455-2526; Vol.03, Issue 03 (2016)

Institute of Research Advances

http://research-advances.org/index.php/IJEMS

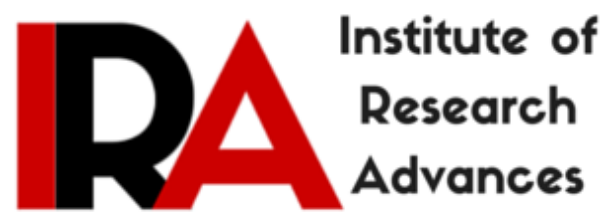

\title{
Collaboration trend in Speech, Language and Hearing Sciences: A Scientometric Study Based on Select Journals
}

\author{
Mr. S. Ramkumar \\ (Research Scholar in Management \\ The Gandhigram Rural Institute -Deemed University) \\ Registrar \\ All India Institute of Speech \& Hearing (AIISH) \\ Manasagangothri, Mysore 570 006, India. \\ Dr. N. Narayanasamy \\ Professor \\ Department of Extension Education \\ The Gandhigram Rural Institute \\ (Deemed University) \\ Gandhigram - 624 302, Dindigul District, Tamil Nadu

\section{Dr. P. Nageswara Rao} \\ Head - Knowledge Centre \\ Society for Electronic Transactions and Security (SETS) \\ MGR Knowledge City, CIT Campus, Taramani, Chennai - 600113 \\ DOI: http://dx.doi.org/10.21013/jems.v3.n3.p22
}

\section{How to cite this paper:}

Ramkumar, S., Narayanasamy, N., \& Nageswara Rao, P. (2016). Collaboration trend in Speech, Language and Hearing Sciences : A Scientometric Study Based on Select Journals. IRA International Journal of Education and Multidisciplinary Studies (ISSN 2455-2526), 3(3). doi:http://dx.doi.org/10.21013/jems.v3.n3.p22

(C) Institute of Research Advances

(cc) BY-NC

This works is licensed under a Creative Commons Attribution-Non Commercial 4.0 International License subject to proper citation to the publication source of the work.

Disclaimer: The scholarly papers as reviewed and published by the Institute of Research Advances (IRA) are the views and opinions of their respective authors and are not the views or opinions of the IRA. The IRA disclaims of any harm or loss caused due to the published content to any party. 


\begin{abstract}
Collaboration trend among researchers can take many forms. One of the most tangible forms of this collaboration is co-authorship. Over the decades the multiple-author publication, frequently referred to as a co-authored publication, has been used as a basic counting unit to measure collaborative activity. In order to identify the collaborative trend in speech, language and hearing science three leading journals such as Journal of Speech, Language and Hearing Research(JSLRH), published by American Speech and Hearing Association (ASHA),Asia Pacific Journal of Speech, Language and Hearing(SLH) and Journal of the All India Institute of Speech and Hearing (JAIISH). A total of 905 articles published in these three journals during the period of 2009-2013 have been considered for the study. Scientometric tools such as Authorship pattern Collaborative Author Index, Degree of Collaboration. Collaboration Index, Collaborative Coefficient and Modified Collaborative Coefficient, Local collaborative index, Domestic collaborative index, International collaborative Index were used. The study shows that there exists collaborative research in speech, language and hearing sciences journals irrespective of the origin of the journal. The local collaboration of authors was more rather than domestic and international collaboration among the authors. The study also shows that there is no significant difference in collaboration in the domain of speech or language or hearing and Local collaboration persist in the domain of speech or language or hearing.
\end{abstract}

Keywords: Collaboration Trend, Local,domestic and international collaboration, Scientometric study, Scientometric tools, Author collaboration.

\title{
1. INTRODUCTION
}

Collaborations among researchers can take many forms. In a sense, there is a continuum ranging from the classic partnership between two faculty members at academic institutions, to situations such as the use by one researcher of another's resources such as a piece of equipment, a biological strain, or a database. Collaborators have expectations as to what the nature of the research relationship should be, including the rights and responsibilities of each party. Sometimes, the term "collaboration" may have different meanings to the collaborators and others who may be directly or indirectly involved. If these differences are not identified early in the relationship, and resolved through clear communication, they can become contentious when researchers' interpretations vary concerning emerging issues such as the access to and use of the data generated, or the ownership of intellectual property.

The result of this collaboration is that in order to complete their research, many scientists collaborate with their peers in other organization, disciplines, and even other countries. ${ }^{1}$ One of the most tangible forms of this collaboration is co-authorship ${ }^{2}$. For decades the multiple-author publication, frequently referred to as a co-authored publication, has been used as a basic counting unit to measure collaborative activity. 


\section{SCIENTOMETRIC STUDY}

Traditionally, bibliometrics have dealt with the study of print-based literature while scientometrics has focused on the statistical analysis of research pattern. The term 'Scientometrics', often used synonymously as 'Bibliometrics', which originated in Russia, is quantitative methods of application in measuring science. The measurement involves counting artefacts to the production and use of information, and arriving conclusions from the counts. The terms like 'Librametrics', 'Bibliometrics', 'Informetrics' and 'Scientometrics' have been used synonymously in order to study the growth of literature in a discipline and other aspects of literature quantitatively.

Scientometrics analyses, the quantitative aspects of science, the quantitative of the Science of Science, of Scientific Communication Studies and of Science Policy Studies. Scientometrics and Informetrics are bound through their mutual interest in scientific literature. Their statistical and mathematical orientation does not preclude analysis by qualitative methods.

\section{REVIEW OF RELATED STUDIES}

Newman $(2004)^{3}$ believes that useful and effective sharing of viewpoints, specialization of scientific disciplines, multi-discipline studies, increasing of research costs, and political factors all played important roles in increasing the level of collaboration between researchers.

Ardanuy $(2011)^{4}$ studied the level of co-authorship of Spanish research in Library and Information Science until 2009 and found that $46 \%$ of papers were published in collaboration within the same institution. Increasing trends were identified in articles with two and three authors. The authorship pattern is consistent with a trend of increasing multiauthorship, which has been identified in previous studies.

A review of the previous studies shows a low collaboration rate between researchers in library and information science discipline where many articles follow a single author pattern. This is in contrast with the scientific collaboration between researchers in Physics, Biology, and Astronomy. [Lee, Melin G Postdoc, Morrison, Osareh $]\left[^{5-7]}\right.$

Despite the limitations of co-authorship measures, many studies have used this technique to investigate collaboration. For example, de Solla Price was an early advocate of the use of multiple-author papers as a measure of changes in collaboration. He produced evidence to support Smith's observation that multiple-authorship has been increasing a trend since confirmed by several other investigators[Balog,D.Deb.D deB, D Deb ${ }^{[8-13]}$ However, such studies have also shown that the rate of increase in multipleauthorship has varied considerably with subject area ${ }^{[14,15]}$, and in a few cases (e.g. biomedicine $^{[16]}$ ) there seems to have been no significant growth.

\section{SCIENTOMETRIC TOOLS}

In this study, scientific collaboration has been measured as follows:

\section{Collaboration Index (CI)}


The simplest of the indices presently employed in the literature is the Collaboration Index, CI, which is to be interpreted merely as the mean number of authors per paper.

$$
\mathrm{CI}=\frac{\sum_{\mathrm{j}=1}^{\mathrm{A}} \mathrm{jf}_{\mathrm{j}}}{\mathrm{N}}
$$

$\mathrm{j}$ is the number of co-authored papers appearing in a discipline; $\mathrm{N}$ is the total number of papers in the discipline over the same time interval, and $\mathrm{k}$ the greatest number of authors per paper in a discipline. As pointed out by Ajiferuke et al $(1988)^{17}$ this is to be interpreted merely as a mean, for in the absence of an upper limit there is no way of interpreting the numbers generated, and secondly the method imputed a nonzero weight to single authored papers. To overcome this index referred to as the degree of collaboration is introduced, where single-author papers have zero-weight.

\section{Degree of Collaboration (DC)}

Subramaniyam $(1983)^{18}$ proposed a mathematical formula for calculating author's degree of collaboration in a discipline. The degree of collaboration among authors is the ratio of the number of collaborative publications in the total number of publications published in a discipline during certain period of time. The values of degree of collaboration can be calculated both for publications and citations. It is expressed mathematically as:

$$
D C=\frac{N_{m}}{N_{m}+N_{s}}
$$

Where

$$
\begin{aligned}
\mathrm{g} & =\text { Group Coefficient of a discipline } \\
\mathrm{N}_{\mathrm{m}}= & \text { Number of multiple authors during a specific period in a discipline } \\
\mathrm{Ns} & =\text { Number of single authored works in a discipline during a given period } \\
& \text { of time. }
\end{aligned}
$$

\section{Collaborative Coefficient (CC)}

The index CC given to overcomes the disadvantages of collaborative index and makes it possible to draw a comparison between different sub-disciplines. In order to make a relevant comparison, consider the collaboration coefficient. The patterns of coauthorship among different countries have been examined by making use of Collaborative Coefficient (CC) suggested by Ajiferuke et al (1988) ${ }^{17}$. The formula used for calculating $\mathrm{CC}$ is given below:

$$
\mathrm{CC}=1-\left[\sum_{\mathrm{j}=1}^{\mathrm{k}}(1 / \mathrm{j}) \mathrm{Fj} / \mathrm{N}\right]
$$

Where as

$$
\begin{aligned}
& \mathrm{Fj}=\text { the number of authored papers } \\
& \mathrm{N}=\text { total number of research published; and } \\
& \mathrm{K}=\text { the greatest number of authors per paper }
\end{aligned}
$$




\section{Modified Collaborative Coefficient (MCC)}

It is lightly modified that the new measure is almost the same as that of CC, as given in Ajiferuke et al $(1988)^{17}$. Consider that every paper takes with it a single "credit", and this credit is being shared with the collaborated authors. Thus if a paper has a single author, the author receives one credit; similarly with 2 authors, each author receives $1 / 2$ credits and, in general, if a publication has $X$ authors, each receives $1=X$ credits (it was the same as that of the idea of fractional productivity defined by Price and Beaver $^{19}$ as the score of an author when he is assigned $1=n$ of a unit for one item for which $\mathrm{n}$ authors have been credited.)

Hence, the average credit awarded to each author of a random paper is $\mathrm{E}[1=\mathrm{X}]$, a value that lies between 0 and 1 . Since the value 0 is corresponding to single authorship, it can be defined as the Modified Collaborative Coefficient (MCC).

$$
\text { MCC }=\frac{A}{A-1}\left\{1-\frac{\sum_{j=1}^{A}(1 / j) f_{j}}{N}\right\}
$$

Where as

$$
\begin{aligned}
& A=\text { Total number of papers of particular year } \\
& N=\text { All total number of authors in collection } \\
& J=\text { the collaboration of number of authors like two, three, four etc. } \\
& f_{j}=\text { all the authors in the collaboration }
\end{aligned}
$$

Co-authorship Index (CAI) has been obtained by calculating proportional output of single, two, three and multi-authored papers for different journals and for different subspecialties of speech, language and hearing sciences. The methodology is similar to one suggested by Price ${ }^{20}$ and used to calculate Activity Index (AI) suggested by Frame ${ }^{21}$ and elaborated by Schubert and Braun ${ }^{22}$.

Here CAI $=\{(\mathbf{N i j} / \mathbf{N i o}) /(\mathbf{N o j} / \mathbf{N o o})\} \times \mathbf{1 0 0}$ where

$\mathrm{Nij}=$ Number of papers having $\mathrm{j}$-authors from journal $\mathrm{i}$,

Nio $=$ Total output of journal $i$,

Noj $=$ Number of papers having $\mathrm{j}$-authors from all the three journals,

Noo $=$ Total output for all journals and $\mathrm{j}=1,2,3$, and $(\geq 4)$. Here 'all' implies all the 3 identified journals.

$\mathrm{CAI}=100$ implies that a journal's co-authorship effort for a particular type of authorship corresponds to the world average, CAI $>100$ reflects higher than average co-authorship effort, and CAI $<100$ lower than average co-authorship effort by that journal for a given type of authorship pattern. The measure is different than what has been suggested by Garg and Pathi ${ }^{23}$. For calculating the co-authorship index for different sub-specialties of speech, language and hearing sciences, journals have been replaced by sub-specialty.

Local Collaborative Index (LCI) has been obtained by calculating proportional output of domestically co-authored papers. 
Here $\boldsymbol{L C I}=\{(\boldsymbol{L i} / \mathbf{L i o}) /(\boldsymbol{L o} / \mathbf{L o o})\} \times \mathbf{1 0 0}$ where

$\mathrm{Li}=$ Number of domestically co-authored papers for journal $\mathrm{i}$,

Lio $=$ Total output for journal $\mathrm{i}$,

Lo $=$ Number of domestically co-authored papers from all journals,

Loo $=$ Total output for all journals. Here 'all' implies all the 3 identified journals.

Domestic Collaborative Index (DCI) has been obtained by calculating proportional output of domestically co-authored papers.

Here DCI $=\{($ Di $/$ Dio $) /($ Do $/$ Doo $)\} \times 100$ where

$\mathrm{Di}=$ Number of domestically co-authored papers for journal $\mathrm{i}$,

Dio $=$ Total output for journal $\mathrm{i}$,

Do $=$ Number of domestically co-authored papers from all journals,

Doo $=$ Total output for all journals. Here 'all' implies all the 3 identified journals.

International Collaborative Index (ICI) has been obtained by calculating proportional output of internationally co-authored papers and is an improvement over internationalization index suggested by Nagpaul ${ }^{24}$.

Here $\mathbf{I C I}=\{(\mathbf{I i} / \mathbf{I i o}) /(\mathbf{I o} / \mathbf{I o o})\} \times \mathbf{1 0 0}$ where

$\mathrm{Ii}=$ Number of internationally co-authored papers for journal $\mathrm{i}$,

Iio $=$ Total output for journal $\mathrm{i}$,

Io $=$ Number of internationally co-authored papers for all journals,

Ioo $=$ Total output for all journals. Here 'all' implies the 3 identified journals.

The value of DCI or ICI = 100 indicate that a country's collaborative effort corresponds to world average. DCI or ICI $>100$ reflects collaboration higher than world average and DCI or ICI $<100$ reflects collaboration less than world average.

\section{OBJECTIVES}

The objectives of the study were

- To identify the type of co-authorship pattern in general as well as in terms of its sub-specialities in the leading journals in the area of speech, language and hearing sciences during 2009 to 2013 and to calculate the co-authorship index.

- To identify the pattern and magnitude of local, domestic and international collaboration in general as well as in terms of its sub-specialities in the leading journals in the area of speech, language and hearing sciences during 2009 to 2013 and to measure the local, domestic and international collaborative index.

\section{HYPOTHESES}

The following hypotheses were formulated for the study.

- There exists collaborative research in speech, language and hearing sciences journals irrespective of the origin of the journal. 
- There exist local collaboration rather than domestic and international collaboration.

- There is no significant difference in collaboration in the domain of speech or language or hearing.

- Local collaboration persist in the domain of speech or language or hearing.

\section{DATA}

Data for the present study are taken from the following leading 3 journals one each from USA, Asia and India in the area of speech, language and hearing sciences:

- Journal of Speech, Language and Hearing Research (JSLHR), published by American Speech and Hearing Association (ASHA), a bimonthly, peerreviewed journal containing basic as well as applied research in normal and disordered communication processes with topics relevant to speech-language pathology and audiology professionals worldwide.

- Speech, Language and Hearing (SLH), a peer-reviewed journal, previously published as Asia Pacific Journal of Speech, Language and Hearing, affiliated with the Asia Pacific Society of Speech, Language and Hearing (SLH), New Zealand Speech-Language Therapists' Association (NZSTA) and Hong Kong Association of Speech Therapists (HKAST)

- Journal of the All India Institute of Speech and Hearing (JAIISH, a peerreviewed official publication of AIISH, Mysore,which carries articles pertaining to the normal and abnormal processes and disorders of Language, Speech and Hearing.

\section{METHODOLOGY}

- The above 3 journals have been identified as they are not only leading journals in the field of speech, language and hearing sciences but they also feature articles from all the three sub-specialities.

- Data for a 5 year time period is used to avoid variations in collaboration pattern.

- A count of the papers by different number of authors (say 1,2,3...) was made. The papers by four authors and above have been clubbed together and would be termed as multiauthored papers.

- The data has been analyzed to identify local (inter- departmental), domestic (inter-institutional), and international collaboration for different nations.

\section{ANALYSIS}

Analysis has been carried out Journal wise, Subject wise, Authorship Pattern

\subsection{Journal wise Distribution}

The journal wise distribution is shown in Table 1 along with percentage. A total of 905 publications taken up for the study. 
Table 1

Distribution of Publications

\begin{tabular}{|c|c|c|c|c|c|c|c|}
\hline $\begin{array}{l}\text { S. } \\
\text { No. }\end{array}$ & $\begin{array}{c}\text { Journal } \\
\text { Name }\end{array}$ & Country & $\begin{array}{c}\text { Number } \\
\text { of } \\
\text { Issues } \\
\end{array}$ & Publications & Percentage & Cumulative & $\begin{array}{l}\text { Cumulative } \\
\text { Percentage }\end{array}$ \\
\hline 1 & JAIISH & India & 6 & 146 & 16.13 & 146 & 16.13 \\
\hline 2 & JSLHR & USA & 12 & 648 & 71.60 & 794 & 87.73 \\
\hline 3 & SLH & Asia-Pacific & 9 & 111 & 12.27 & 905 & 100.00 \\
\hline \multicolumn{4}{|c|}{ Total } & 905 & 100 & & \\
\hline
\end{tabular}

Out of 905 publications ,146 (16.13) publications belongs to India based journal JAIISH. It is followed by 648 (71.60) publications of USA based journal JSLHR and 111 (12.27) publications are Asia-Pacific based journal SLH. These 905 publications, were published over 5 year period (2009-2013). Year wise distribution of articles are shown in Table 2.

It can be seen from Table 2, that the number of papers in each year wasre around $17.68 \%$ to $22.65 \%$. So number of papers during the 5 year period were in linear trend. Similarly for each journal, the number of papers for each year, showed a linear trend.

Table 2

Journal Vs Year wise Distribution of Publications

\begin{tabular}{|c|c|c|c|c|c|}
\hline \multirow{2}{*}{$\begin{array}{c}\text { S. } \\
\text { No. }\end{array}$} & Year & JAIISH & JSLHR & SLH & Total \\
\cline { 3 - 6 } & $\begin{array}{c}\text { No. of } \\
\text { Papers }\end{array}$ & $\begin{array}{c}\text { No. of } \\
\text { Papers }\end{array}$ & $\begin{array}{c}\text { No. of } \\
\text { Papers }\end{array}$ & $\begin{array}{c}\text { No. of } \\
\text { Papers }\end{array}$ \\
\hline 1 & 2009 & $\begin{array}{c}25 \\
(17.12)\end{array}$ & $\begin{array}{c}112 \\
(17.28)\end{array}$ & $\begin{array}{c}23 \\
(20.72)\end{array}$ & $\begin{array}{c}160 \\
(17.68)\end{array}$ \\
\hline 2 & 2010 & $\begin{array}{c}34 \\
(23.29)\end{array}$ & $\begin{array}{c}124 \\
(19.14)\end{array}$ & $\begin{array}{c}20 \\
(18.02)\end{array}$ & $\begin{array}{c}178 \\
(19.67)\end{array}$ \\
\hline 3 & 2011 & $\begin{array}{c}28 \\
(19.18)\end{array}$ & $\begin{array}{c}119 \\
(18.36)\end{array}$ & $\begin{array}{c}23 \\
(20.72)\end{array}$ & $\begin{array}{c}170 \\
(18.78)\end{array}$ \\
\hline 4 & 2012 & $\begin{array}{c}28 \\
(19.18)\end{array}$ & $\begin{array}{c}144 \\
(22.22)\end{array}$ & $\begin{array}{c}20 \\
(18.02)\end{array}$ & $\begin{array}{c}192 \\
(21.22)\end{array}$ \\
\hline 5 & 2013 & $\begin{array}{c}31 \\
(21.23)\end{array}$ & $\begin{array}{c}149 \\
(22.99)\end{array}$ & $\begin{array}{c}25 \\
(22.52)\end{array}$ & $\begin{array}{c}205 \\
(22.65)\end{array}$ \\
\hline \multicolumn{2}{|c|}{ Total } & $\begin{array}{c}\mathbf{1 4 6} \\
(\mathbf{1 0 0})\end{array}$ & $\begin{array}{c}\mathbf{6 4 8} \\
(\mathbf{1 0 0})\end{array}$ & $\begin{array}{c}\mathbf{1 1 1} \\
(\mathbf{1 0 0})\end{array}$ & $\begin{array}{c}\mathbf{9 0 5} \\
(\mathbf{1 0 0})\end{array}$ \\
\hline
\end{tabular}

\subsection{Authorship Pattern}

The Authorship pattern of these articles both overall and for individual journals are shown in Table 3.

Table 3

Authorship Pattern

\begin{tabular}{|c|c|c|c|c|c|}
\hline \multirow{2}{*}{$\begin{array}{c}\text { S. } \\
\text { No. }\end{array}$} & \multirow{2}{*}{$\begin{array}{l}\text { No. of } \\
\text { Authors }\end{array}$} & JAIISH & JSLHR & SLH & Total \\
\hline & & $\begin{array}{l}\text { No. of } \\
\text { Papers }\end{array}$ & $\begin{array}{l}\text { No. of } \\
\text { Papers }\end{array}$ & No. of Papers & $\begin{array}{l}\text { No. of } \\
\text { Papers }\end{array}$ \\
\hline 1 & $\begin{array}{l}\text { Single } \\
\text { Author }\end{array}$ & $\begin{array}{c}5 \\
(3.42)\end{array}$ & $\begin{array}{c}45 \\
(6.95)\end{array}$ & $\begin{array}{c}13 \\
(11.71)\end{array}$ & $\begin{array}{c}63 \\
(6.96)\end{array}$ \\
\hline
\end{tabular}




\begin{tabular}{|c|c|c|c|c|c|}
\hline 2 & Two Author & $\begin{array}{c}50 \\
(34.25)\end{array}$ & $\begin{array}{c}181 \\
(27.93)\end{array}$ & $\begin{array}{c}31 \\
(27.93)\end{array}$ & $\begin{array}{c}262 \\
(28.95)\end{array}$ \\
\hline 3 & $\begin{array}{l}\text { Three } \\
\text { Authors }\end{array}$ & $\begin{array}{c}54 \\
(36.99)\end{array}$ & $\begin{array}{c}171 \\
(26.39)\end{array}$ & $\begin{array}{c}35 \\
(31.53)\end{array}$ & $\begin{array}{c}260 \\
(28.73)\end{array}$ \\
\hline 4 & $\begin{array}{l}\text { Four and } \\
\text { above }\end{array}$ & $\begin{array}{c}37 \\
(25.34)\end{array}$ & $\begin{array}{c}251 \\
(38.73)\end{array}$ & $\begin{array}{c}32 \\
(28.83)\end{array}$ & $\begin{array}{c}320 \\
(35.36)\end{array}$ \\
\hline & Total & $\begin{array}{c}146 \\
(100)\end{array}$ & $\begin{array}{c}648 \\
(100)\end{array}$ & $\begin{array}{c}111 \\
(100)\end{array}$ & $\begin{array}{c}905 \\
(100)\end{array}$ \\
\hline
\end{tabular}

The overall single author publications works out to $63(6.96 \%)$, followed by two authors 262 (28.95\%), three authors 260 (28.73\%) and four and above 320 (35.36\%). It can be inferred that the collaborative research persist in speech, language and hearing sciences journals. In the case of JAIISH - India based journal $96.58 \%$ were collaborated research whereas in USA based journals - JSLHR $93.05 \%$ were collaborated and in the case of Asia Pacific journal - SLH, 88.29\% were collaborative in nature. Further it can be seen that the Indian contributions as solo research is to the extent of $11.71 \%$.

The CAI, thus calculated for the authorship pattern for individual journals are shown in Table 4 along with CAI in coded form i.e. if CAI $>100$ indicated as ++ and $<100$ indicated as - - .

Table 4

CAI for Authorship Pattern

\begin{tabular}{|c|l|c|c|c|c|c|c|c|c|c|c|}
\hline \multirow{2}{*}{$\begin{array}{c}\text { S. } \\
\text { No. }\end{array}$} & $\begin{array}{c}\text { No. of } \\
\text { Authors }\end{array}$ & $\begin{array}{c}\text { No. of } \\
\text { Papers }\end{array}$ & CAI & $\begin{array}{c}\text { CAI - } \\
\text { Coded }\end{array}$ & $\begin{array}{c}\text { No. of } \\
\text { Papers }\end{array}$ & CAI & $\begin{array}{c}\text { CAI - } \\
\text { Coded }\end{array}$ & $\begin{array}{c}\text { JSL. of } \\
\text { Papers }\end{array}$ & CAI & $\begin{array}{c}\text { CAI - } \\
\text { Coded }\end{array}$ & $\begin{array}{c}\text { No. of } \\
\text { Papers }\end{array}$ \\
\hline 1 & $\begin{array}{l}\text { Single } \\
\text { Author }\end{array}$ & 5 & 49.2 & -- & 45 & 99.78 & -- & 13 & 168.27 & ++ & 63 \\
\hline 2 & $\begin{array}{l}\text { Two } \\
\text { Author }\end{array}$ & 50 & 118.3 & ++ & 181 & 96.48 & -- & 31 & 97.47 & -- & 262 \\
\hline 3 & $\begin{array}{l}\text { Three } \\
\text { Authors }\end{array}$ & 54 & 128.7 & ++ & 171 & 91.85 & -- & 35 & 109.75 & ++ & 260 \\
\hline 4 & $\begin{array}{l}\text { Four and } \\
\text { above }\end{array}$ & 37 & 71.67 & -- & 251 & 109.54 & ++ & 32 & 81.53 & -- & 320 \\
\hline & Total & $\mathbf{1 4 6}$ & & & $\mathbf{6 4 8}$ & & & $\mathbf{1 1 1}$ & & & $\mathbf{9 0 5}$ \\
\hline
\end{tabular}

It can be seen from Table 4 from that CAI for two authors and three authors in the case of JAIISH positive in nature. Similarly in the case of JSLHR, the CAI is positive in 4 and above authors only. Similarly in the case of SLH single author and three authors are positive in nature. It can be inferred that JAIISH contains more of two and three author papers whereas ,JSLHR contains four and above authors are more. In the case of SLH, it contains single and three author papers are more, compared to two and four and above authors. The DC, CI and CC were also calculated journal wise and the same is shown in Table 5.

Table 5

DC, CI and CC

\begin{tabular}{|c|c|c|c|c|c|c|c|c|c|}
\hline \multirow{2}{*}{$\begin{array}{l}\text { S. } \\
\text { No. }\end{array}$} & \multirow{2}{*}{ Name of the Journal } & \multirow{2}{*}{$\begin{array}{l}\text { Single } \\
\text { Author }\end{array}$} & \multirow{2}{*}{$\begin{array}{c}\text { Two } \\
\text { Authors }\end{array}$} & \multirow{2}{*}{$\begin{array}{c}\text { Three } \\
\text { Authors }\end{array}$} & \multirow{2}{*}{$\begin{array}{c}\text { Four and } \\
\text { Above } \\
\text { Authors }\end{array}$} & \multirow[t]{2}{*}{ Total } & \multirow[t]{2}{*}{ DC } & \multirow[t]{2}{*}{ CI } & \multirow[t]{2}{*}{$\mathrm{CC}$} \\
\hline & & & & & & & & & \\
\hline 1 & JAIISH & 5 & 50 & 54 & 37 & 146 & 0.97 & 3.10 & 0.62 \\
\hline 2 & JSLHR & 45 & 181 & 171 & 251 & 648 & 0.93 & 3.36 & 0.63 \\
\hline 3 & SLH & 13 & 31 & 35 & 32 & 111 & 0.88 & 3.06 & 0.58 \\
\hline & Total & 63 & 262 & 260 & 320 & 905 & 0.93 & 3.28 & 0.62 \\
\hline
\end{tabular}


In all the three journals, the degree of collaboration is more than $93 \%$, the collaborative index indicates that the majority of the papers were three authors. The collaborative coefficient shows that the collaboration is only $62 \%$ and it ranges between $58 \%$ and $63 \%$ in the case of individual journals. It can be also inferred that, the Indian journal as lees collaboration comparing to foreign journals.

The year wise DC. CI, CC and MCC were calculated using the formula stated above and the same is shown in Table 6.

Table 6

DC. CI, CC and MCC Vs Year wise

\begin{tabular}{|c|c|c|c|c|c|c|c|c|c|}
\hline & Single & $\begin{array}{c}\text { Two } \\
\text { Yuthors }\end{array}$ & $\begin{array}{c}\text { Three } \\
\text { Authors }\end{array}$ & $\begin{array}{c}\text { Four and Above } \\
\text { Authors }\end{array}$ & Total & DC & CI & CC & MCC \\
\hline 2009 & 20 & 46 & 37 & 57 & 160 & 0.88 & 3.18 & 0.58 & 0.73 \\
\hline 2010 & 10 & 49 & 51 & 68 & 178 & 0.94 & 3.38 & 0.63 & 0.79 \\
\hline 2011 & 14 & 45 & 50 & 61 & 170 & 0.92 & 3.29 & 0.62 & 0.77 \\
\hline 2012 & 11 & 54 & 63 & 64 & 192 & 0.94 & 3.27 & 0.63 & 0.78 \\
\hline 2013 & 8 & 68 & 59 & 70 & 205 & 0.96 & 3.27 & 0.63 & 0.79 \\
\hline Total & $\mathbf{6 3}$ & $\mathbf{2 6 2}$ & $\mathbf{2 6 0}$ & $\mathbf{3 2 0}$ & $\mathbf{9 0 5}$ & $\mathbf{0 . 9 3}$ & $\mathbf{3 . 2 8}$ & $\mathbf{0 . 6 2}$ & $\mathbf{0 . 7 7}$ \\
\hline
\end{tabular}

It can be seen from table 6 , the collaboration trend increases the over the period,. It can be inferred that the collaborative trend is of recent trend only from the year 2010 onwards. The modified collaborative coefficient indicates that $77 \%$ were collaboration in nature.

Further DC, CI, CC and MCC were calculated for JAIISH and the same is shown in Table 7.

Table 7

DC. CI, CC and MCC Vs Year wise (JAIISH)

\begin{tabular}{|c|c|c|c|c|c|c|c|c|c|}
\hline & $\begin{array}{c}\text { Single } \\
\text { Author }\end{array}$ & $\begin{array}{c}\text { Two } \\
\text { Authors }\end{array}$ & $\begin{array}{c}\text { Three } \\
\text { Authors }\end{array}$ & $\begin{array}{c}\text { Four and Above } \\
\text { Authors }\end{array}$ & Total & DC & CI & CC & MCC \\
\hline 2009 & 2 & 7 & 13 & 3 & 25 & 0.92 & 2.80 & 0.58 & 0.73 \\
\hline 2010 & 0 & 10 & 12 & 12 & 34 & 1.00 & 3.41 & 0.66 & 0.83 \\
\hline 2011 & 1 & 7 & 9 & 11 & 28 & 0.96 & 3.46 & 0.65 & 0.82 \\
\hline 2012 & 2 & 10 & 11 & 5 & 28 & 0.93 & 2.86 & 0.58 & 0.73 \\
\hline 2013 & 0 & 16 & 9 & 6 & 31 & 1.00 & 2.87 & 0.61 & 0.76 \\
\hline Total & $\mathbf{5}$ & $\mathbf{5 0}$ & $\mathbf{5 4}$ & $\mathbf{3 7}$ & $\mathbf{1 4 6}$ & $\mathbf{0 . 9 7}$ & $\mathbf{3 . 1 0}$ & $\mathbf{0 . 6 2}$ & $\mathbf{0 . 7 8}$ \\
\hline
\end{tabular}

The degree of collaboration of JAIISH works out to $97 \%$ which indicates that the majority of the articles are collaborative in nature. In the year 2010 and 2013 all the papers have appeared in collaboration. The CI indicates that the average author per paper between 2 and 3 authors. Three, four and above authors paper were more during 2010 and 2011. The CC shows the inconsistency in collaboration. The MCC also indicates the same. In both the case the coefficient values were increasing over the year 2010 and slowly reduces over the years. 
The DC, CI, CC and MCC were calculated for JSLHR and the same is shown in Table 8 .

Table 8

DC. CI, CC and MCC Vs Year wise (JSLHR)

\begin{tabular}{|c|c|c|c|c|c|c|c|c|c|}
\hline Year & $\begin{array}{c}\text { Single } \\
\text { Author }\end{array}$ & $\begin{array}{c}\text { Two } \\
\text { Authors }\end{array}$ & $\begin{array}{c}\text { Three } \\
\text { Authors }\end{array}$ & $\begin{array}{c}\text { Four and Above } \\
\text { Authors }\end{array}$ & Total & DC & CI & CC & MCC \\
\hline 2009 & 11 & 32 & 22 & 47 & 112 & 0.90 & 3.36 & 0.61 & 0.76 \\
\hline 2010 & 9 & 34 & 31 & 50 & 124 & 0.93 & 3.39 & 0.63 & 0.78 \\
\hline 2011 & 12 & 33 & 32 & 42 & 119 & 0.90 & 3.23 & 0.60 & 0.75 \\
\hline 2012 & 7 & 39 & 42 & 56 & 144 & 0.95 & 3.41 & 0.64 & 0.80 \\
\hline 2013 & 6 & 43 & 44 & 56 & 149 & 0.96 & 3.38 & 0.64 & 0.80 \\
\hline Total & $\mathbf{4 5}$ & $\mathbf{1 8 1}$ & $\mathbf{1 7 1}$ & $\mathbf{2 5 1}$ & $\mathbf{6 4 8}$ & $\mathbf{0 . 9 3}$ & $\mathbf{3 . 3 6}$ & $\mathbf{0 . 6 3}$ & $\mathbf{0 . 7 8}$ \\
\hline
\end{tabular}

The degree of collaboration of JSLHR works out to 93\% which indicates that the majority of the articles are collaborative in nature. The CI indicates that the average author per paper between 3 and above. The CC shows the inconsistency in collaboration. The MCC also indicates the same. In both the case the coefficient values were increasing over the year 2010 and slowly reduces over the years. in Table 9.

Similarly DC, CI, CC and MCC were calculated for SLH and the same is shown

Table 9

DC. CI, CC and MCC Vs Year wise (SLH)

\begin{tabular}{|c|c|c|c|c|c|c|c|c|c|}
\hline Year & $\begin{array}{c}\text { Single } \\
\text { Author }\end{array}$ & $\begin{array}{c}\text { Two } \\
\text { Authors }\end{array}$ & $\begin{array}{c}\text { Three } \\
\text { Authors }\end{array}$ & $\begin{array}{c}\text { Four and Above } \\
\text { Authors }\end{array}$ & Total & DC & CI & CC & MCC \\
\hline 2009 & 7 & 7 & 2 & 7 & 23 & 0.70 & 2.70 & 0.45 & 0.57 \\
\hline 2010 & 1 & 5 & 8 & 6 & 20 & 0.95 & 3.25 & 0.63 & 0.79 \\
\hline 2011 & 1 & 5 & 9 & 8 & 23 & 0.96 & 3.39 & 0.65 & 0.81 \\
\hline 2012 & 2 & 5 & 10 & 3 & 20 & 0.90 & 2.85 & 0.58 & 0.72 \\
\hline 2013 & 2 & 9 & 6 & 8 & 25 & 0.92 & 3.12 & 0.60 & 0.75 \\
\hline Total & $\mathbf{1 3}$ & $\mathbf{3 1}$ & $\mathbf{3 5}$ & $\mathbf{3 2}$ & $\mathbf{1 1 1}$ & $\mathbf{0 . 8 8}$ & $\mathbf{3 . 0 6}$ & $\mathbf{0 . 5 8}$ & $\mathbf{0 . 7 3}$ \\
\hline
\end{tabular}

The degree of collaboration of SLH works out to $88 \%$ which indicates that the majority of the articles are collaborative in nature. The CI indicates that the average author per paper between 2 and 3 authors. Three, four and above authors paper were more during 2010 and 2011. The CC shows the inconsistency in collaboration. The MCC also indicates the same. In both the case the coefficient values were increasing over the year 2010, 2011 and slowly reduces over the years. Further it can be inferred that SLH has less collaborated papers. 


\subsection{Subject Wise}

In order to identify the subject wise collaboration, the number of papers in each journal on four major subjects such as Speech , Language, Hearing and Others has been identified and same is shown in Table 10.

Table 10

Journal Vs Subject wise Distribution of Publications

\begin{tabular}{|c|c|c|c|c|c|}
\hline \multirow{2}{*}{ S. No. } & \multirow{2}{*}{ Subject } & JAIISH & JSLHR & SLH & Total \\
\hline & & No. of Papers & No. of Papers & No. of Papers & No. of Papers \\
\hline 1 & Speech & $\begin{array}{c}56 \\
(38.36) \\
\end{array}$ & $\begin{array}{c}238 \\
(36.73) \\
\end{array}$ & $\begin{array}{c}40 \\
(36.04) \\
\end{array}$ & $\begin{array}{c}334 \\
(36.91) \\
\end{array}$ \\
\hline 2 & Language & $\begin{array}{c}57 \\
(39.04) \\
\end{array}$ & $\begin{array}{c}255 \\
(39.35) \\
\end{array}$ & $\begin{array}{c}48 \\
(43.24) \\
\end{array}$ & $\begin{array}{c}360 \\
(39.78) \\
\end{array}$ \\
\hline 3 & Hearing & $\begin{array}{c}32 \\
(21.92) \\
\end{array}$ & $\begin{array}{c}150 \\
(23.15) \\
\end{array}$ & $\begin{array}{c}12 \\
(10.81) \\
\end{array}$ & $\begin{array}{c}194 \\
(21.44) \\
\end{array}$ \\
\hline 4 & Others & $\begin{array}{c}1 \\
(0.68)\end{array}$ & $\begin{array}{c}5 \\
(0.77) \\
\end{array}$ & $\begin{array}{c}11 \\
(9.91)\end{array}$ & $\begin{array}{c}17 \\
(1.87) \\
\end{array}$ \\
\hline & Total & $\begin{array}{c}146 \\
(100)\end{array}$ & $\begin{array}{c}648 \\
(100)\end{array}$ & $\begin{array}{c}111 \\
(100)\end{array}$ & $\begin{array}{c}905 \\
(100)\end{array}$ \\
\hline
\end{tabular}

$36.91 \%$ of articles were on the subject Speech, it is followed by Language (39.78\%) and Hearing (21.44\%). Only $1.87 \%$ of the articles appeared other than the three subjects. It can be inferred that the number of articles in each subject almost proportionate. The same trend can be seen in individual journals too. However in the case of SLH nearly $10 \%$ of the articles were other than Speech, Language and Hearing subject.

Authorship pattern under each subject has been identified and the same is shown in Table 11.

Table 11

Authorship Pattern Vs Subject

\begin{tabular}{|c|c|c|c|c|c|c|}
\hline \multirow[b]{2}{*}{$\begin{array}{c}\text { S. } \\
\text { No. }\end{array}$} & \multirow[b]{2}{*}{$\begin{array}{c}\text { No. of } \\
\text { Authors }\end{array}$} & Speech & Language & Hearing & Others & Total \\
\hline & & No. of Papers & No. of Papers & $\begin{array}{l}\text { No. of } \\
\text { Papers }\end{array}$ & $\begin{array}{l}\text { No. of } \\
\text { Papers }\end{array}$ & $\begin{array}{l}\text { No. of } \\
\text { Papers }\end{array}$ \\
\hline 1 & Single Author & $\begin{array}{c}24 \\
(7.25)\end{array}$ & $\begin{array}{c}25 \\
(6.87)\end{array}$ & $\begin{array}{c}14 \\
(7.25)\end{array}$ & $\begin{array}{c}0 \\
(0.00)\end{array}$ & $\begin{array}{c}63 \\
(6.96)\end{array}$ \\
\hline 2 & Two Author & $\begin{array}{c}94 \\
(28.40)\end{array}$ & $\begin{array}{c}110 \\
(30.22)\end{array}$ & $\begin{array}{c}54 \\
(27.98)\end{array}$ & $\begin{array}{c}4 \\
(23.53)\end{array}$ & $\begin{array}{c}262 \\
(28.95)\end{array}$ \\
\hline 3 & Three Authors & $\begin{array}{c}92 \\
(27.79)\end{array}$ & $\begin{array}{c}96 \\
(26.37)\end{array}$ & $\begin{array}{c}63 \\
(32.64)\end{array}$ & $\begin{array}{c}9 \\
(52.94)\end{array}$ & $\begin{array}{c}260 \\
(28.73)\end{array}$ \\
\hline 4 & $\begin{array}{l}\text { Four and } \\
\text { above }\end{array}$ & $\begin{array}{c}121 \\
(36.56) \\
\end{array}$ & $\begin{array}{c}133 \\
(36.54) \\
\end{array}$ & $\begin{array}{c}62 \\
(32.12)\end{array}$ & $\begin{array}{c}4 \\
(23.53)\end{array}$ & $\begin{array}{c}320 \\
(35.36)\end{array}$ \\
\hline & Total & $\begin{array}{c}331 \\
(100)\end{array}$ & $\begin{array}{c}364 \\
(100)\end{array}$ & $\begin{array}{c}193 \\
(100)\end{array}$ & $\begin{array}{c}17 \\
(100)\end{array}$ & $\begin{array}{c}905 \\
(100)\end{array}$ \\
\hline
\end{tabular}

In the case of Speech subject, out of 331 papers 24 (7.25\%) belongs to single author paper. It is followed by 97 (28.40\%) two author paper, 92 (27.79\%) three authors and $121(36.56 \%)$ four and above author papers. Similarly in the case of Language subject, out of 334 papers $25(6.87 \%)$ belongs to single author paper. It is followed by 110 (30.22\%) two author paper, 96 (26.37\%) three authors and 133 (36.54\%) four and above author papers. In the case of Hearing subject, out of 193 papers 14 (7.25\%) 
belongs to single author paper. It is followed by 54 (27.98\%) two author paper, 63 (32.64\%) three authors and $62(32.12 \%)$ four and above author papers. Similarly in the case of Others subject all 17 papers were collaborative in nature. Out of 17 papers, 4 (23.53\%) belongs to two author paper. It is followed by $9(52.94 \%)$ three authors and 4 (23.53\%) four and above author papers.

The DC, CI and CC for each subject were calculated and same is shown in Table

12.

Table 12

DC, CI and CC Vs Subject

\begin{tabular}{|c|l|c|c|c|c|c|c|c|c|}
\hline $\begin{array}{l}\text { S. } \\
\text { No. }\end{array}$ & Subject & $\begin{array}{c}\text { Single } \\
\text { Author }\end{array}$ & $\begin{array}{c}\text { Two } \\
\text { Authors }\end{array}$ & $\begin{array}{c}\text { Three } \\
\text { Authors }\end{array}$ & $\begin{array}{c}\text { Four and } \\
\text { Above } \\
\text { Authors }\end{array}$ & Total & DC & CI & CC \\
\hline 1 & Speech & 24 & 94 & 92 & 121 & 331 & 0.93 & 3.30 & 0.62 \\
\hline 2 & Language & 25 & 110 & 96 & 133 & 364 & 0.93 & 3.29 & 0.62 \\
\hline 3 & Hearing & 14 & 54 & 63 & 62 & 193 & 0.93 & 3.22 & 0.61 \\
\hline 4 & others & 0 & 4 & 9 & 4 & 17 & 1.00 & 3.24 & 0.66 \\
\hline \multicolumn{2}{|l|}{ Total } & $\mathbf{6 3}$ & $\mathbf{2 6 2}$ & $\mathbf{2 6 0}$ & $\mathbf{3 2 0}$ & $\mathbf{9 0 5}$ & $\mathbf{0 . 9 3}$ & $\mathbf{3 . 2 8}$ & $\mathbf{0 . 6 2}$ \\
\hline
\end{tabular}

The DC for all the four subjects works out to 93\%. Further it can be seen from the table 12 that the DC of three subjects namely Speech, Language and Hearing were identical i.e. 93\%. The CI indicates that the average author per paper on each subject ranges between 3 and 4 . The CC also almost identical for the three subjects.

\subsection{Collaboration Nature - Local, Domestic and International}

The study further extended to nature of collaboration such as Local, Domestic and International for individual journals and overall. The same is shown in Table 13

Out of 905 papers, $(366,40.44 \%)$ were local collaboration. It is followed by domestic collaboration $(344,38.01 \%)$ and international collaboration $(132,14.59 \%)$. In the case of JAIISH out of 146 papers, 105 (71.92\%) were local collaboration. It is followed by domestic collaboration $(29,19.861 \%)$ and international collaboration (7, 4.79\%). As far as JAIISH is concerned, local collaboration is more since it is an Indian based publication. It is surprised to see $7(4.79 \%)$ international collaborated papers. Similarly, JSLHR out of 648 papers, $219(33.80 \%)$ were local collaboration. It is followed by domestic collaboration $(280,43.21 \%)$ and international collaboration (104, $16.05 \%)$. As far as JSLHR is concerned, domestic and local collaboration is more since it is an USA publication. In the case of SLH, out of 111 papers, 42 (37.84\%) were local collaboration. It is followed by domestic collaboration $35(31.53 \%)$ and international collaboration $21(18.92 \%)$. As far as SLH is concerned, both local and domestic collaboration were evenly poised. Whereas this journal has $19 \%$ international collaboration. Of course it is interesting to note that nearly $13(11.71 \%)$ has no collaboration. 
Table 13

Nature of Collaboration

\begin{tabular}{|c|c|c|c|c|c|}
\hline \multirow{2}{*}{$\begin{array}{c}\text { S. } \\
\text { No. }\end{array}$} & \multirow{2}{*}{ Collaboration } & JAIISH & JSLHR & SLH & \multirow{2}{*}{$\begin{array}{l}\text { Total } \\
\text { No. of } \\
\text { Papers }\end{array}$} \\
\hline & & No. of Papers & No. of Papers & No. of Papers & \\
\hline 1 & Local & $\begin{array}{c}105 \\
(71.92)\end{array}$ & $\begin{array}{c}219 \\
(33.80)\end{array}$ & $\begin{array}{c}42 \\
(37.84)\end{array}$ & $\begin{array}{c}366 \\
(40.44)\end{array}$ \\
\hline 2 & Domestic & $\begin{array}{c}29 \\
(19.86)\end{array}$ & $\begin{array}{c}280 \\
(43.21)\end{array}$ & $\begin{array}{c}35 \\
(31.53)\end{array}$ & $\begin{array}{c}344 \\
(38.01)\end{array}$ \\
\hline 3 & International & $\begin{array}{c}7 \\
(4.79)\end{array}$ & $\begin{array}{c}104 \\
(16.05)\end{array}$ & $\begin{array}{c}21 \\
(18.92)\end{array}$ & $\begin{array}{c}132 \\
(14.59)\end{array}$ \\
\hline 4 & No Collaboration & $\begin{array}{c}5 \\
(3.42) \\
\end{array}$ & $\begin{array}{c}45 \\
(6.94)\end{array}$ & $\begin{array}{c}13 \\
(11.71)\end{array}$ & $\begin{array}{c}63 \\
(6.96)\end{array}$ \\
\hline & Total & $\begin{array}{c}146 \\
(100)\end{array}$ & $\begin{array}{c}648 \\
(100) \\
\end{array}$ & $\begin{array}{c}111 \\
(100)\end{array}$ & $\begin{array}{c}905 \\
(100) \\
\end{array}$ \\
\hline
\end{tabular}

The collaborative index for local, domestic and international and the same is shown in Table 14.

Table 14

LCI, DCI, ICI Vs Journal

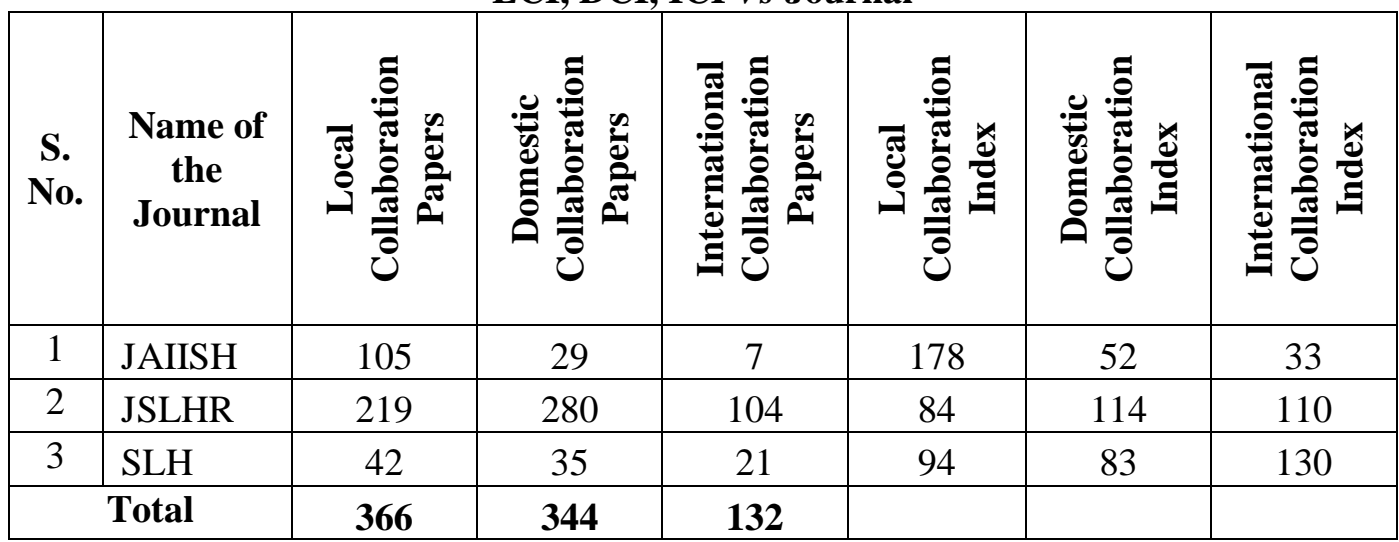

It can be seen from the table 14, that local collaborative index of JAIISH is more compared to JSLHR and SLH. In the case of JSLHR, domestic collaboration index is more compared to SLH and JAIISH. The international collaboration index is more in SLH and JSLHR.

The subject wise Nature of Collaboration were identified and same is shown in Table 15. Out of 331 papers in Speech, $132(39.88 \%)$ has local collaboration. It is followed by $120(36.25 \%)$ papers as domestic collaboration papers and $55(16.62 \%)$ papers as international collaboration. Similarly in the case of Language, out of 364, 147 $(40.38 \%)$ has local collaboration. It is followed by $139(38.19 \%)$ papers as domestic collaboration papers and $53(14.56 \%)$ papers as international collaboration. In the case of Hearing ,out of 193, 83 (43.01\%) has local collaboration. It is followed by 74 (38.34\%) papers as domestic collaboration papers and $22(11.40 \%)$ papers as international collaboration. In the case of Others, all the 17 papers were collaborative in nature, of which, $5(29.41 \%)$ belongs to local collaboration. It is followed by $9(52.94 \%)$ papers as domestic collaboration papers and $3(17.65 \%)$ papers as international collaboration. In general the local collaboration was more irrespective of the subject such as Speech, 
Language and Hearing followed by domestic and international. The ratio of collaboration between international, domestic and local were 1:2.57:2.75.

Table 15

Nature of Collaboration Vs Subject

\begin{tabular}{|c|c|c|c|c|c|c|}
\hline \multirow[b]{2}{*}{ S. No. } & \multirow[b]{2}{*}{ Collaboration } & \multirow{2}{*}{\begin{tabular}{|c|c|} 
Speech \\
$\begin{array}{c}\text { No. of } \\
\text { Papers }\end{array}$
\end{tabular}} & \multirow{2}{*}{$\begin{array}{c}\text { Language } \\
\begin{array}{c}\text { No. of } \\
\text { Papers }\end{array}\end{array}$} & \multirow{2}{*}{$\begin{array}{c}\text { Hearing } \\
\begin{array}{c}\text { No. of } \\
\text { Papers }\end{array}\end{array}$} & \multirow{2}{*}{$\begin{array}{l}\text { Others } \\
\begin{array}{l}\text { No. of } \\
\text { Papers }\end{array}\end{array}$} & \multirow{2}{*}{$\begin{array}{l}\text { Total } \\
\text { No. of } \\
\text { Papers }\end{array}$} \\
\hline & & & & & & \\
\hline 1 & Local & $\begin{array}{c}132 \\
(39.88) \\
\end{array}$ & $\begin{array}{c}147 \\
(40.38) \\
\end{array}$ & $\begin{array}{c}83 \\
(43.01) \\
\end{array}$ & $\begin{array}{c}5 \\
(29.41) \\
\end{array}$ & $\begin{array}{c}367 \\
(40.55) \\
\end{array}$ \\
\hline 2 & Domestic & $\begin{array}{c}120 \\
(36.25)\end{array}$ & $\begin{array}{c}139 \\
(38.19)\end{array}$ & $\begin{array}{c}74 \\
(38.34)\end{array}$ & $\begin{array}{c}9 \\
(52.94)\end{array}$ & $\begin{array}{c}342 \\
(37.79)\end{array}$ \\
\hline 3 & International & $\begin{array}{c}55 \\
(16.62) \\
\end{array}$ & $\begin{array}{c}53 \\
(14.56)\end{array}$ & $\begin{array}{c}22 \\
(11.40)\end{array}$ & $\begin{array}{c}3 \\
(17.65)\end{array}$ & $\begin{array}{c}133 \\
(14.70)\end{array}$ \\
\hline 4 & No Collaboration & $\begin{array}{c}24 \\
(7.25) \\
\end{array}$ & $\begin{array}{c}25 \\
(6.87) \\
\end{array}$ & $\begin{array}{c}14 \\
(7.25) \\
\end{array}$ & $\begin{array}{c}0 \\
(0.00) \\
\end{array}$ & $\begin{array}{c}63 \\
(6.96) \\
\end{array}$ \\
\hline & Total & $\begin{array}{c}331 \\
(100)\end{array}$ & $\begin{array}{c}364 \\
(100)\end{array}$ & $\begin{array}{c}193 \\
(100)\end{array}$ & $\begin{array}{c}17 \\
(100)\end{array}$ & $\begin{array}{c}905 \\
100)\end{array}$ \\
\hline
\end{tabular}

The local, domestic and international collaborative index for subject wise were calculated and the same is shown in Table 16.

Table 16

LCI, DCI, ICI Vs Subject

\begin{tabular}{|c|c|c|c|c|c|c|c|}
\hline S. No. & Subject & 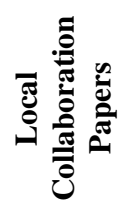 & 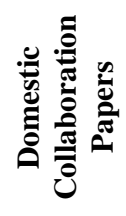 & 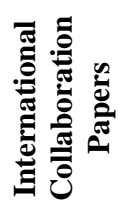 & 胥 & 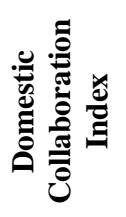 & 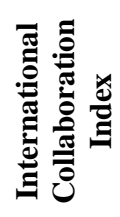 \\
\hline 1 & Speech & 132 & 120 & 55 & 98.34 & 95.93 & 113.07 \\
\hline 2 & Language & 147 & 139 & 53 & 99.59 & 101.05 & 99.08 \\
\hline 3 & Hearing & 83 & 74 & 22 & 106.05 & 101.46 & 77.56 \\
\hline 4 & Others & 5 & 9 & 3 & 72.53 & 140.09 & 120.08 \\
\hline
\end{tabular}

In the case of Speech, international collaborative index is more compared to local and domestic collaborative index. Whereas in Language, domestic collaborative index is more compared to local and international. Similarly in the case of Hearing, local collaborative index is more, followed by domestic and international collaboration.

\section{FINDINGS}

\section{The findings of the study are:}

- Collaboration trend on Speech, Language and Hearing sciences has been identified using three journals namely Journal of Speech, Language and Hearing Research(JSLHR), Asia Pacific Journal of Speech, Language and Hearing (SLH) and Journal of the All India Institute of Speech and Hearing (JAIISH).

- A total of 905 articles, published in these three journals during the period of 2009-2013. The number of papers during the study period in these three journals is linear in trend. 
- Single author publications works out to $63(6.96 \%)$, it is followed by two authors $262(28.95 \%)$, three authors $260(28.73 \%)$ and four and above 320 (35.36\%). It can be inferred that the collaborative research persist in speech, language and hearing sciences journals.

- In the case of India based journal- JAIISH, 96.58\% were collaborated research whereas in USA based journal - JSLHR $93.05 \%$ were collaborated and in the case of Asia-Pacific journal - SLH, 88.29\% were collaborated in nature.

- Indian contributions show solo research to the extent of $11.71 \%$.

- In all the three journals, the degree of collaboration is more than $93 \%$, the collaborative index indicates that the majority of the papers were three authors. The collaborative coefficient shows that the collaboration is only $62 \%$ and it ranges between $58 \%$ and $63 \%$ in the case of individual journals. It can be also inferred that, the Indian journal has less collaboration compared to foreign journals.

- The collaboration trend increases the over the period. Iit can be inferred that the collaborative trend is of recent trend only from the year 2010 onwards. The modified collaborative coefficient indicates that $77 \%$ were collaboration in nature.

- The degree of collaboration of JAIISH works out to $97 \%$ which indicates that the majority of the articles are collaborative in nature. In the year 2010 and 2013 all the papers thus appear in collaboration in nature. The average author per paper between 2 and 3 authors. Three, four and above authors paper were more during 2010 and 2011. .

- The degree of collaboration of JSLHR works out to 93\% which indicates that the majority of the articles are collaborative in nature. The average author per paper between 3 and above were more during 2010 and 2011. The CC shows the inconsistency in collaboration. The MCC also indicates the same.

- The degree of collaboration of SLH works out to $88 \%$ which indicates that the majority of the articles are collaborative in nature. The CI indicates that the average author per paper between 2 and 3 authors. Three, four and above authors paper were more during 2010 and 2011. The CC shows the inconsistency in collaboration. The MCC also indicates the same. In both the case the coefficient values were increasing over the year 2010, 2011 and slowly reduces over the years. Further it can be inferred that SLH has less collaborated papers.

- $36.91 \%$ of articles were in Speech, followed by Language $(39.78 \%)$ and Hearing $(21.44 \%)$. Only $1.87 \%$ of the articles appeared other than the three subjects. It can be inferred that the number of articles in each subject almost proportionate. The same trend can be seen in individual journals too. However in the case of SLH, nearly $10 \%$ of the articles were other than Speech, Language and Hearing subject.

- $\quad$ Speech has 331 papers, 24 (7.25\%) belongs to single author paper, 97 (28.40\%) two author paper, 92 (27.79\%) three authors and 121 (36.56\%) four and above author papers. In Language, out of 334 papers, 25 (6.87\%) belongs to single author paper. It is followed by $110(30.22 \%)$ two author paper, $96(26.37 \%)$ three authors and 133 (36.54\%) four and above author papers. In Hearing, out of 193 papers, $14(7.25 \%)$ belongs to single author paper. It is followed by $54(27.98 \%)$ two author paper, 63 (32.64\%) three authors and $62(32.12 \%)$ four and above author papers. Other than the above three subjects there exist 17 papers, which were all collaborative in nature. Out of 17 papers, $4(23.53 \%)$ belongs to two 
author paper. It is followed by 9 (52.94\%) three authors and 4 (23.53\%) four and above author papers.

- Out of 905 papers, $366(40.44 \%)$ were local collaboration, 344 (38.01\%) domestic collaboration and $132(14.59 \%)$ international collaboration.

- JAIISH has $105(71.92 \%)$ local collaboration. 29 (19.86\%) domestic collaboration and $7(4.79 \%)$. international collaboration. In JAIISH, local collaboration is more and it is a Indian based publication. It has 7 (4.79\%) international collaborated papers.

- JSLHR has 219 (33.80\%) local collaboration, 280 (43.21\%),domestic collaboration and $104(16.05 \%)$ international collaboration. As far as JSLHR is concern domestic and local collaboration is more and it is USA publication.

- $\quad$ SLH has $42(37.84 \%)$ local collaboration, 35 (31.53\%) domestic collaboration and $21(18.92 \%)$ international collaboration As far as SLH is concerned, both local and domestic collaboration were evenly poised. Whereas this journal has $19 \%$ international collaboration. Nearly $13(11.71 \%)$ has no collaboration.

\section{CONCLUSION}

The scientometric study thus carried using the three journals viz., Journal of Speech, Language and Hearing Research), Speech, Language and Hearing and Journal of the All India Institute of Speech and Hearing for identifying the collaboration trend shows that there exists collaborative research in speech, language and hearing sciences journals irrespective of the origin of the journal. The local collaboration of authors were more rather than domestic and international collaboration among the authors. The study also shows that there is no significant difference in collaboration in the domain of speech or language or hearing and Local collaboration persist in the domain of speech or language or hearing. Only 905 papers have been studied to find the collaboration trend. Therefore the finding may be indicative in nature. Exhaustive study in this domain may pave way for getting accuracy in the study.

\section{REFERENCES}

1. Hayati Z, Didegah F. International Scientific collaboration among Iranian researchers during 1998- 2007. Library Hi Tech. 2010;28:433-46.

2. Glanzel W, Schubert A. Netherlands: Kluwer Academic Publishers; 2004. Analyzing scientific networks through co-authorship. Handbook of quantitative science and technology research.

3. Newman ME. Co-authorship networks and patterns of scientific collaboration. Proc Natl Acad Sci U S A. 2004;101:5200-4.

4. Ardanuy, J. (2011). Scientific Collaboration in Library and Information Science viewed through the Web of Knowledge: the Spanish Case. Scientometrics, DOI 10.1007/s11192-011-0552-1.

5. Lee S, Bozeman B. The Impact of Research collaboration on Scientific Productivity. Soc Stud Sci. 2005;35:703-23.

6. Melin G. Postdoc Abroad: Inherited scientific contacts or establishment of new network. Res Eval. 2004;13:95-102.

7. Morison PS, Dobbieb G, McDonaldc FJ. Research collaboration among university Scientists. High Educ Res Dev. 2003;22:275-96.

8. Osareh F. In Proceedings of 10th International Conference on Scientometrics and Informetric. Stockholm, Sweden: Proceedings of 10th International Conference on Scientometrics and Informetric; 2006. Jul 24-28, Collaboration in astronomy knowledge production: A case study in science direct from 2000-2004. 
9. C. Balog, Multiple Authorship and Author Collaboration in Agricultural Research Publications, Journal of Research Communication Studies 2 (1979/80) 159-69.

10. D. deB. Beaver and R. Rosen, Studies in Scientific Collaboration: Part I - The Professional Origins of Scientific Co-authorship, Scientometrics 1 (1978) 65-84.

11. D. deB. Beaver and R. Rosen, Studies in Scientific Collaboration: Part II Scientific Coauthorship, Research Productivity and Visibility in the French Scientific Elite, 1799- 1830, Scientometrics 1 (1979a) 133-49.

12. D. deB. Beaver and R. Rosen, Studies in Scientific Collaboration: Part III Professionalization and the Natural History of Modern Scientific Co-authorship, Scientometrics 1 (1979b) 231-45.

13. A.J. Meadows and J.G. O'Connor, 1971, Bibliographic statistics as a guide to growth points in science, Science Studies 1, 95-99.

14. R.K. Merton, 1965, The ambivalence of scientists, in: N. Kaplan (editor), Science and Society (Rand McNally, Chicago), pp. 112-132

15. B. Stefaniak, 1982, Individual and multiple authorship of papers in chemistry and physics, Scientometrics 4, 331-337.

16. B.L. Clarke, 1964, Multiple authorship trends in scientific papers, Science 143, 822-824.

17. Ajiferuke, I., Burrel, Q., \& Tague, J. (1988). Collaborative coefficient: A single measure of the degree of collaboration in research. Scientometrics, 14, 421-433.

18. Subramanian, K. (1983). Bibliometric studies of research collaboration: A review. Journal of Information Science, 6(1): 33-38.

19. De Solla Price, D. J. and Beaver, D. de B. (1966). Collaboration in an invisible college, American Psychologist, 21(11):1011-1018.

20. De Solla Price, D. (1981). The analysis of scientomeric metrics for policy implications. Scientometrics, 3(1):47-54.

21. Frame, J. D. (1977). Mainstream research in Latin America and the Caribbean, Interciencia (Caracas), 2 (3):143-148

22. Schubert, A. and Braun, T. (1986). Relative indicators and relational charts for comparative assessment of publication output and citation impact. Scientometrics, 9 (5-6): 281-291.

23. Garg, K. C. and Padhi, P. (1998) Scientometric Study of Laser Patent Literature, Scientometrics, 43(3):443-454.

24. Nagpaul, P. S. (1999). Transnational linkages of Indian science: a structural analysis. Scientometrics, 46(1):109-140. 